\title{
用于神经形态计算的 $\mathrm{CsPbBr}_{3}$ 钻铁矿忆阻器性能研究
}

\author{
倪梓全, 郑悦婷, 胡海龙, 郭太良, 李福山 ${ }^{*}$ \\ 福州大学物理与信息工程学院, 福州 350116 \\ *联系人, E-mail: fsli@fzu.edu.cn \\ 2021-02-15 收稿, 2021-03-24 修回, 2021-04-28 接受, 2021-04-30 网络版发表 \\ 国家自然科学基金(62075043)资助
}

\begin{abstract}
摘要 忆阻器可以模拟生物突触行为而实现低功耗、并行计算、集成度高的神经形态计算, 因此已经引起广泛关 注。本文报道了一种基于溶液法制备的铯铅溴 $\left(\mathrm{CsPbBr}_{3}\right)$ 钙钛矿忆阻器, 以包裹在聚乙烯吡咯烷酮 (PVP) 中的 $\mathrm{CsPBr}_{3}$ 为功能层的忆阻器表现出优异的空气稳定性, 同时成功模拟了生物突触行为, 包括突触可塑性( synaptic plasticity)、长时程增强(long-term potentiation, LTP)和短时程增强(short-term potentiation, STP)、幅度依赖可塑 性、双脉冲易化 (paired-pulse facilitation, PPF)、短期记忆和长期记忆以及两者的转变. 本研究展示的制备简单、 成本低、稳定性好的钙钛矿人工突触, 为未来神经形态计算的应用提供了新的可能性.
\end{abstract}

关键词铯铅溴, 钻钛矿, 忆阻器, 神经形态计算, 人工突触

在过去的十几年里, 数据量的激增使得人工神经 网络越来越受到人们的关注, 并且应用于多个领域, 例 如图像与自然语言处理、自动驾驶、金融和生物信息 处理等 ${ }^{[1]}$. 目前的人工神经网络是利用传统计算机体系 通过软件算法来实现的, 其能耗高且效率较低 ${ }^{[2,3]}$. 基于 冯·诺依曼架构的传统计算机体系的特点是存储单元 与计算单元分离，在两者间的数据交换过程中消耗大 量能源, 同时速度的提升也遭遇瓶颈 ${ }^{[4]}$. 由于计算单元 的运算速度远比存储单元的读写速度快, 在两者的数 据交换过程中计算单元必须消耗额外的时间等待存储 单元完成读写, 由此带来的速度限制称之为冯·诺依曼 瓶颈 ${ }^{[5]}$. 而人脑通过神经元和突触可以实现计算和存 储同步进行，有着可并行计算、功耗小、计算力大等 特点 ${ }^{[6]}$. 因此, 模拟生物突触来实现神经形态计算是打 破冯. 诺依曼瓶颈的可行方案 ${ }^{[7,8]}$. 在生物大脑中, 学习 与记忆行为与突触可塑性有直接的关系, 突触间的连 接强度受到神经元活动的影响而得到增强或抑制 ${ }^{[9]}$.
忆阻器是一种非线性电阻, 该元器件是1971年Chua ${ }^{[10]}$ 从电路理论完备性角度出发预测出电阻、电容、电感 之外的第4种无源基本电路元件, 其阻值能够随输人电 流或电压的历史而发生变化, 这与突触可塑性相似, 因 此忆阻器被广泛认为是模拟生物突触实现神经形态计 算的理想器件 ${ }^{[11]}$.

近十多年来，基于忆阻器的人工突触已有广泛报 道, 所用的阻变材料主要有金属氧化物 ${ }^{[12]}$ 和硫化

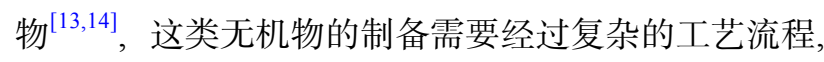
制备成本较高. 金属卤素钙钛矿因其可溶液制备、成 本低廉、可大面积制备且具有优秀电学特性, 如电子 捕获行为、光传输域大、电阻率高、反铁磁性、压电 性、可光致发光、宽温度范围的阴离子电导率等，广 泛应用在光电器件研究中 ${ }^{[15 ~ 18]}$. 基于以上优点, 金属卤 素钙钛矿也是作为阻变层来制备人工突触极具竞争力 的材料 ${ }^{[19]}$. 目前, 以金属卤素钙钛矿作为阻变材料来制 备忆阻器也有所报道. Gong等人 ${ }^{[20]}$ 使用 $\mathrm{CsPbBr}_{3}$ 量子点 
成功制备出拥有模拟型忆阻特性的三端口忆阻器. 但 由于该横向结构器件的沟道长度过长以及界面效应使 得器件需要 $40 \mathrm{~V}$ 以上的高操作电压, 同时量子点的制 备和复杂的器件结构也需要复杂的工艺而增加了制备 成本, 其突触可塑性也不够明显. John等人 ${ }^{[21]}$ 使用有机无机杂化卤素钲钛矿制备出 5 层结构的人工突触, 由于 有机-无机杂化卤素钻钛矿对环境敏感，该器件依然面 临稳定性的挑战. $\mathrm{Wu}$ 等人 ${ }^{[22]}$ 通过添加 $\mathrm{ZnO}$ 来提高铯铅 溴 $\left(\mathrm{CsPbBr}_{3}\right)$ 忆阻器的稳定性, 但未能模拟出生物突触 功能, 只应用在存储领域中. 因此, 目前的卤素钻钛矿 人工突触器件依然存在突触可塑性和稳定性不足的问 题. 鉴于金属卤素钙钛矿的优异特性和神经形态计算 的迫切需求，有必要进一步探索制备出成本低廉、制 备工艺简易、稳定性好且性能高的人工突触器件.

本文报道了一种基于溶液法制备的氧化铟锡(indium tin oxide, ITO)/CsPbBr 3 : 聚乙烯吡咯烷酮(PVP)/Au 忆阻器. 阻变层使用 $\mathrm{CsPbBr}_{3}$ 前驱体和PVP混合溶液旋 涂在ITO玻璃上, 通过高温退火生长出 $\mathrm{CsPBBr}_{3}$ 晶体, 晶 体被PVP包裹而隔断大气避免被氧化, 从而得到稳定性 高的忆阻器件. ITO/CsPbBr 3 : $\mathrm{PVP} / \mathrm{Au}$ 忆阻器表现出稳 定且重复性高的阻变特性; 同时该器件实现了生物突 触功能的模拟，包括突触可塑性(synaptic plasticity)、 长时程增强(long-term potentiation, LTP)和短时程增强 (short-term potentiation, STP)、幅度依赖可塑性、双脉 冲易化 (paired-pulse facilitation，PPF)、短期记忆和长 期记忆以及两者的转变. 得益于良好的稳定性和突触 功能模拟, ITO/CsPbBr 3 : $\mathrm{PVP} / \mathrm{Au}$ 忆阻器有望在神经形 态计算领域得以应用, 打破传统计算体系的瓶颈.

\section{1 实验}

实验中使用的溶液为 $\mathrm{CsPbBr}_{3} 、 \mathrm{PVP}$ 混合溶液 $\left(\mathrm{CsPbr}_{3}: \mathrm{PVP}\right)$, 将 $\mathrm{CsBr}$ 和 $\mathrm{PbBr}_{2}$ 以 $1: 1$ 的摩尔比溶于二 甲基亚砜 (dimethyl sulfoxide, DMSO)中，浓度为 $0.1 \mathrm{~mol} / \mathrm{L}$, 并添加 $50 \mathrm{mg} / \mathrm{mL}$ 的PVP, 剧烈搅拌至完全溶 解. 所用基片使用清洗液、去离子水、乙醇、丙酮依 次在超声机和清洗机中各清洗 $15 \mathrm{~min}$. 器件制备在氮 气环境中进行, 器件制备流程: 首先在刻蚀有图案化 ITO的玻璃基板上滴加混合溶液; 然后以 $2000 \mathrm{r} / \mathrm{min}$ 的 速度旋涂 $60 \mathrm{~s}$ ，随后放置于加热台上以 $250^{\circ} \mathrm{C}$ 的温度退 火 $15 \mathrm{~min}$; 最后使用掩膜板盖住器件，蒸镀约 $65 \mathrm{~nm}$ 厚 的图形化电极 Au. 器件结构示意图如图1(a)所示.

器件的电学测试在大气环境中进行, 温度为 $300 \mathrm{~K}$,
测试设备为Keithley 4200-SCS. 在测试过程中, 对下电 极(ITO)电气接地，电压信号施加在上电极 $\mathrm{Au}$ 上; 使用 源-测量单元(source-measure unit)进行测试，该模块可 以同时对器件施加电压信号并测量器件的响应电流.

\section{2 结果与讨论}

\section{1 忆阻器阻变层形貌表征}

器件的扫描电子显微镜(SEM)截面如图1(b)所示, 可以看到 $\mathrm{CsPBr}_{3}$ 纳米晶粒位于上下电极之间，晶粒间 的空隙被PVP填充; PVP隔断了上下电极的直接接触, 避免器件短路, 同时包裹 $\mathrm{CsPbBr}_{3}$ 晶粒以隔绝 $\mathrm{CsPbBr}_{3}$ 晶粒与大气环境直接接触, 避免被氧化. $\mathrm{CsPbBr}_{3}: \mathrm{PVP}$ 层表面形貌如图1(c)所示, 右图为未经过退火处理的膜 层形貌，左图的膜层分别经过 250 和 $300^{\circ} \mathrm{C}$ 退火处理 $15 \mathrm{~min}$. 从图中可以看出, 没有经过退火处理所形成的 $\mathrm{CsPbr}_{3}$ 晶粒尺寸较小，晶粒间隙中存在未完全结晶的 颗粒; 而经过 250 和 $300^{\circ} \mathrm{C}$ 退火后的器件形成大颗粒、 结晶度高的膜层. X射线衍射(XRD)结果(图1(d))进一 步显示了该现象, 经过 $250^{\circ} \mathrm{C}$ 退火的钙钛矿层在 $15.25^{\circ} 、 21.71^{\circ} 、 30.78^{\circ}$ 的衍射峰明显, 分别对应 (001)、(110)、(002)晶面; 而未经过退火处理的钻钛矿 层由于结晶度较弱, 衍射峰不明显, 只检测到1个(110) 晶面(ICDD PDF\#00-018-0364). 因此, 经过 $250^{\circ} \mathrm{C}$ 退火 的 $\mathrm{CsPbr}_{3}$ : $\mathrm{PVP}$ 膜层可以得到晶粒较大、结晶度高的 $\mathrm{CsPbBr}_{3}$ 晶体.

为了探究阻变层的元素分布, 对经过 $250^{\circ} \mathrm{C}$ 退火的 $\mathrm{CsPbBr}_{3}: \mathrm{PVP}$ 膜层进一步表征，在 $15 \mathrm{kV}$ 的电压下获得 的能谱仪(EDS)分析结果如图2所示. 从图中可以发现, $\mathrm{Cs} 、 \mathrm{~Pb} 、 \mathrm{Br}$ 三种元素聚集在晶体所在区域，其中 $\mathrm{Br}$ 的 含量最高, 集聚性最明显; 3 种元素的摩尔比为 $\mathrm{Cs}(\mathrm{L})$ : $\mathrm{Pb}(\mathrm{M}): \mathrm{Br}(\mathrm{L})=17.28: 21.55: 61.17$, 约 1:1:3, 符合 $\mathrm{CsPbBr}_{3}$ 的原子比. 以上结果说明 $\mathrm{CsBr} 、 \mathrm{PbBr}_{2} 、 \mathrm{PVP}$ 混合溶液 在经过退火处理后, $\mathrm{CsBr}$ 与 $\mathrm{PbBr}_{2}$ 结合生成 $\mathrm{CsPbBr}_{3}$ 钙 钛矿纳米晶体.

\section{2 忆阻器的阻变特性与突触行为模拟}

$\mathrm{ITO} / \mathrm{CsPbBr} 3: \mathrm{PVP} / \mathrm{Au}_{\mathrm{a}}^{\mathrm{g}}$ 件的电流-电压 $(I-V)$ 特性如 图3所示. 在器件电极上施加 $0 \rightarrow 2 \rightarrow 0 \mathrm{~V}$ 、以 $0.02 \mathrm{~V}$ 为步 进的递增电压, 之后施加 $0 \rightarrow-2 \rightarrow 0 \mathrm{~V}$ 的反向递增电压. 图3(a) 为纵轴取对数处理的 $I-V$ 曲线, 退火后器件的 $I-V$ 曲线展现出良好的滞回行为. 在初次扫描时, $0 \rightarrow 1.3 \mathrm{~V}$ 
(a)

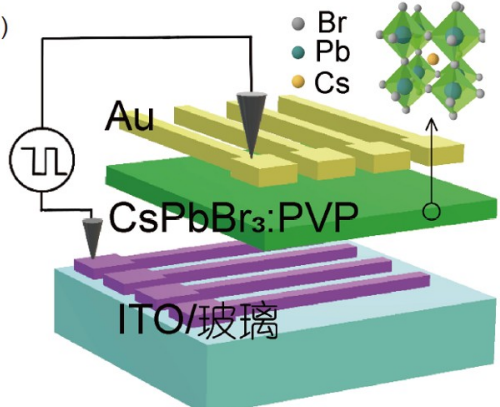

(c)

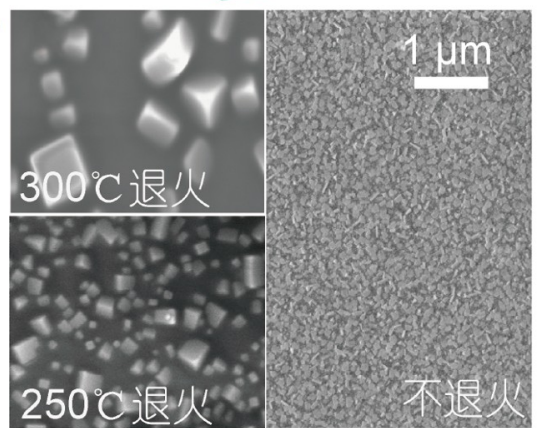

(b)

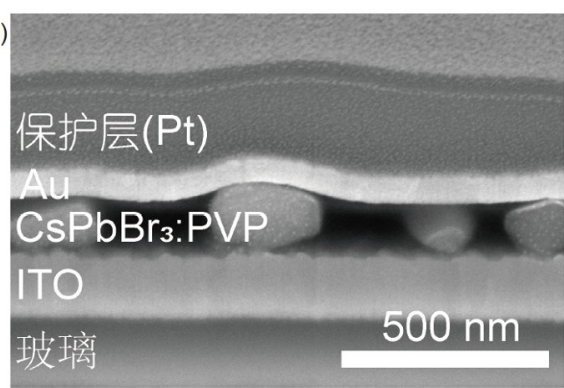

(d)

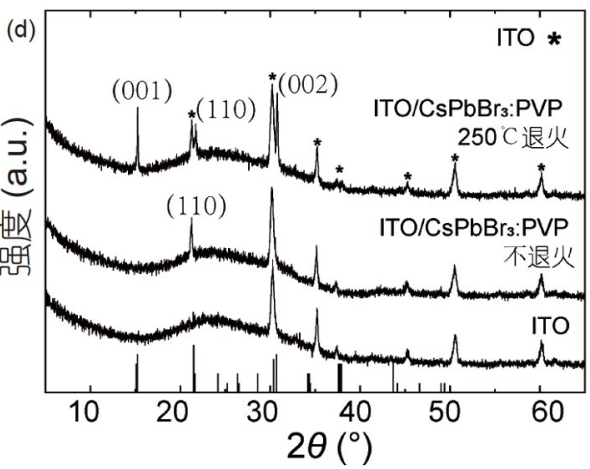

图 1 (网络版彩色)器件结构与表征结果. (a) Glass/ITO/CsPbBr $: \mathrm{PVP} / \mathrm{Auu}$ 怛器的结构示意图, 右上角为 $\mathrm{CsPbBr}$ 晶体的结构图; (b) glass/ITO/ $\mathrm{CsPbBr}_{3}: \mathrm{PVP} / \mathrm{Au}$ 忆阻器的截面图; (c) 经过 $250^{\circ} \mathrm{C}$ 退火(左下)、 $300^{\circ} \mathrm{C}$ 退火(左上)和未经退火(右)的 $\mathrm{CsPbBr}_{3}: \mathrm{PVP}$ 层 $\mathrm{SEM}$ 形貌图; $(\mathrm{d}) \mathrm{CsPbBr}$ : $\mathrm{PVP}$ 膜层的XRD测试结果, 上、中、下曲线分别代表 $250^{\circ} \mathrm{C}$ 退火、未退火的ITO/CsPbBr 3 : $\mathrm{PVP}$ 器件和纯ITO层的测试结果

Figure 1 (Color online) Structure and characterization results of the device. (a) Glass/ITO/CsPbBr $: \mathrm{PVP} / \mathrm{Au}$ memristor structure diagram. The upper right corner is the structure of $\mathrm{CsPbr}_{3}$ crystal. (b) SEM image cross-sectional view of glass/ITO/CsPbBr $: \mathrm{PVP} / \mathrm{Au}$ memristor. (c) SEM topography of $\mathrm{CsPbBr}: \mathrm{PVP}$ layer annealed at $250^{\circ} \mathrm{C}$ (top left)、 $300^{\circ} \mathrm{C}$ (bottom left) and unannealed (right). (d) XRD results of $\mathrm{CsPbBr}$ : $\mathrm{PVP}$ film, in which the ITO/ $\mathrm{CsPbBr}$ : $\mathrm{PVP}$ device of $250^{\circ} \mathrm{C}$ annealed and unannealed, and pure ITO layer shown in up, middle, and down line, respectively
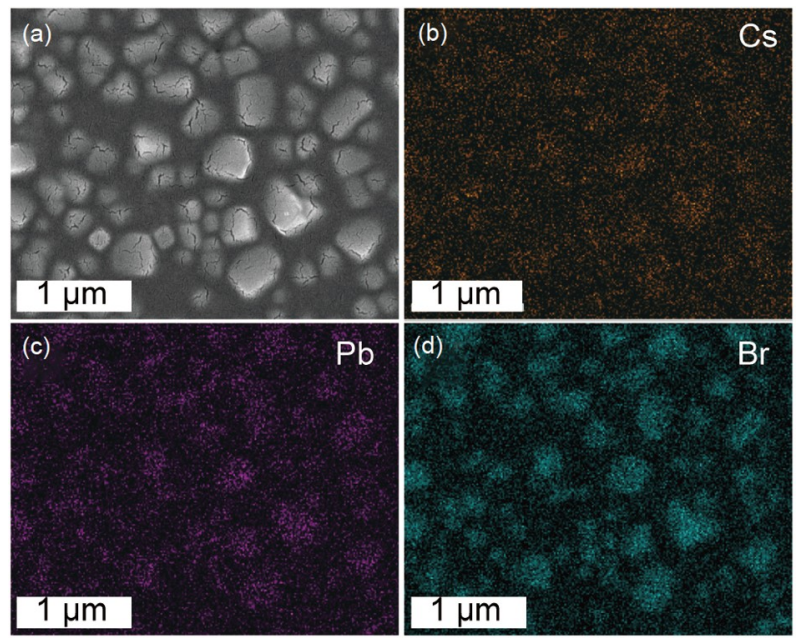

图 2 (网络版彩色) $250^{\circ} \mathrm{C}$ 退火处理的 $\mathrm{CsPbBr}_{3}: \mathrm{PVP}$ 膜层的EDS测试 结果. (a) 膜层表面 $\mathrm{SEM}$ 图; $\mathrm{Cs}(\mathrm{b}) 、 \mathrm{~Pb}(\mathrm{c})$ 和 $\mathrm{Br}(\mathrm{d})$ 元素在(a)所示区域的 含量分布图

Figure 2 (Color online) EDS test of $\mathrm{CsPbBr}_{3}: \mathrm{PVP}$ film annealed at $250^{\circ} \mathrm{C}$. (a) SEM image of film surface. The content distribution of Cs (b), $\mathrm{Pb}(\mathrm{c})$ and $\mathrm{Br}(\mathrm{d})$ in the area shown in (a)

过程中为高阻态(high resistance state, HRS), 在 $1.3 \rightarrow 2 \mathrm{~V}$ 过程中逐渐向低阻态(low resistance state,
LRS)转变, 实现SET操作; 并且在 $2 \rightarrow 0$ 和 $0 \rightarrow-2 \mathrm{~V}$ 过程 中保持HRS. 随后在 $-2 \rightarrow 0 \mathrm{~V}$ 过程中逐渐向LRS转变, 实现RESET操作. 对器件施加多次扫描循环，如图1(b) 所示, 随着扫描次数的增加, 正电压扫描时, 电流滞回 曲线逐渐上移, 表现出电导逐渐增大的情况; 而在反向 电压扫描时, 滞回曲线向电流变小的方向移动, 表明器 件电导逐渐减小。多次 $I-V$ 扫描曲线说明ITO $/ \mathrm{CsPbBr}_{3}$ : $\mathrm{PVP} / \mathrm{Au}$ 器件具有忆阻特性, 即电导随流经器件的电流 变化而变化 ${ }^{[23]}$. 制备完成的器件暴露在大气环境 $\left(10^{5} \mathrm{~Pa}, 300 \mathrm{~K}\right) 9 \mathrm{~d}$ 后, 对器件进行相同的 $I-V$ 测试, 结果 显示依然保持良好的忆阻特性(图3(c))，说明高温退火 形成的钲钛矿晶体在PVP包裹下对大气环境有着良好 的稳定性，为忆阻器的实际应用提供了良好的稳定性 条件. 相同的制备条件下, 只添加PVP的ITO/PVP/Au器 件在电学测试中没有展现出滞回行为(图3(d)), $I-V$ 曲线 呈线性, 说明该条件下的忆阻特性由 $\mathrm{CsPbr}_{3}$ 晶体贡献. 而对于在相同条件下制备的ITO/CsPbBr $3 / \mathrm{Au}^{\mathrm{g}}$ 件(图3 (e)), $I-V$ 曲线呈直线, 且在 $1.8 \mathrm{~V}$ 时电流达到预设的限制 电流 (100 mA). 其原因可能是在未添加PVP的情况下 

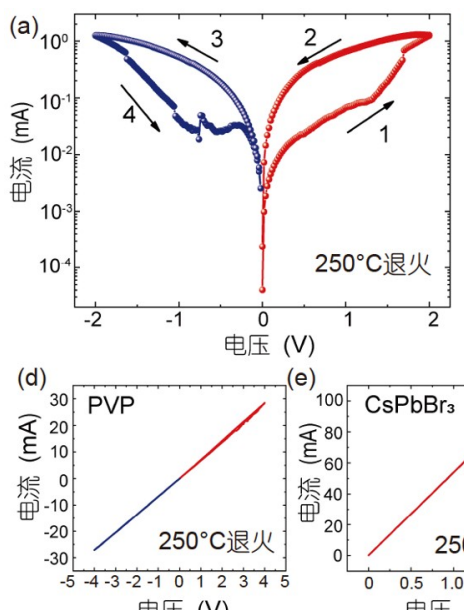

电压 $(V)$
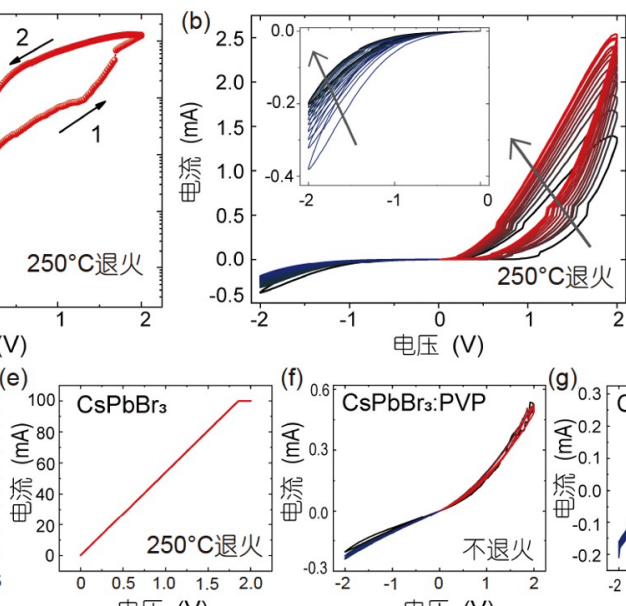

电压 $(\mathrm{V})$

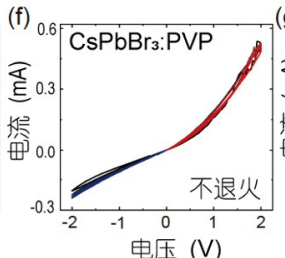

电压 $(\mathrm{V})$

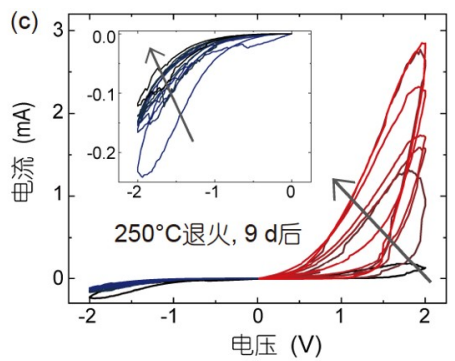

(h)

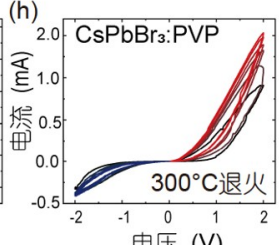

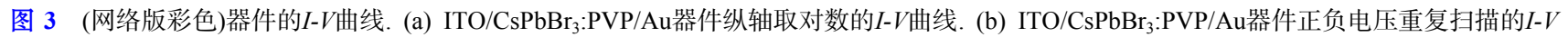
曲线. 插图为负电压扫描部分放大图. (c) ITO/CsPbBr$: \mathrm{PVP} / \mathrm{Au}_{\mathrm{a}}^{\mathrm{a}}$ 件暴露于大气中 (温度约 $\left.300 \mathrm{~K}\right) 9 \mathrm{~d}$ 后的 $I-V$ 曲线. $\mathrm{ITO} / \mathrm{PVP} / \mathrm{Au}(\mathrm{d})$ 和ITO/CsPbBr$/$

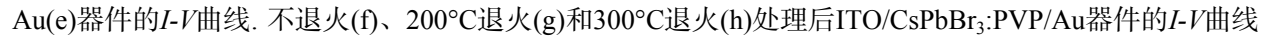

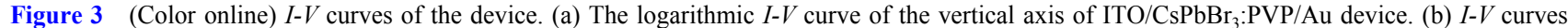
repeated scanning with positive and negative voltages of $\mathrm{ITO} / \mathrm{CsPbB} \mathrm{Pb}_{3}: \mathrm{PVP} / \mathrm{Au}$ device. The inset is an enlarged view of the negative voltage scanning part. (c) $I-V$ curves of $I T O / \mathrm{CsPBr}_{3}: \mathrm{PVP} / \mathrm{Au}$ devices after $9 \mathrm{~d}$ of exposure to the atmosphere at a temperature of about $300 \mathrm{~K}$. $I-V$ curves of ITO/PVP/Au (d) and $\mathrm{ITO} / \mathrm{CsPbBr}_{3} / \mathrm{Au}$ devices (e). The $I-V$ curves of $\mathrm{ITO} / \mathrm{CsPbBr}: \mathrm{PVP} / \mathrm{Au}$ device after unannealed (f), annealed at $200^{\circ} \mathrm{C}(\mathrm{g})$ and annealed at $300^{\circ} \mathrm{C}(\mathrm{h})$

$\mathrm{CsPbBr}_{3}$ 晶体间的空隙过大, 导致上电极蒸镀时 $\mathrm{Au}$ 微粒 通过空隙与下电极直接接触造成器件短路. 对于没有 经过退火处理的器件, 并没有表现出明显的滞回窗口 (图3(f)); 相比于 $250^{\circ} \mathrm{C}$ 退火处理, 在 200 和 $300^{\circ} \mathrm{C}$ 退火处 理后的器件则滞回行为表现更弱, 多次循环扫描的电 流变化也更小(图3(g)、(h)), 即器件阻值变化幅度相对 更小. 推测阻变层中的 $\mathrm{CsPbBr}_{3}$ 结晶状态受到退火温度 影响, 过低或过高温度下所形成的 $\mathrm{CsPbBr}_{3}$ 晶体阻变层 导致较差的忆阻特性, 因此下文中所用器件均在 $250^{\circ} \mathrm{C}$ 退火条件下制备.

在人脑中，学习与记忆行为与神经元之间的突触 可塑性有关 ${ }^{[24]}$. 图4(a)给出了神经元和突触的示意图, 突触前膜传输过来的信号可以使突触后膜产生兴奋性 后突触电流(excitatory post-synaptic currents, EPSCs)或 抑制性后突触电流(inhibitory post-synaptic currents, IPSCs). 神经元之间的连接强度(又称为突触权重)受到 刺激信号的控制，突触权重通过神经元活动得以增强 (potentiation)或抑制(depression) ${ }^{[25]}$. 为了模拟突触可塑 性, 对 $\mathrm{ITO} / \mathrm{CsPbBr}$ : $\mathrm{PVP} / \mathrm{Au}$ 器件上电极施加 50 个的连 续尖峰脉冲 $(2 \mathrm{~V}, 50 \mathrm{~ms})$, 每个脉冲后以低电压尖峰脉 冲 $(0.3 \mathrm{~V}, 50 \mathrm{~ms})$ 来实时读取该时刻的电导值, 随后施 加同数量的反向连续尖峰脉冲(图4(b)). 测试结果如图 4(c)所示, 在正向连续尖峰脉冲刺激下, 器件电导逐渐 增大, 对应生物学中突触权重增强的过程; 而在反向连
续脉冲刺激下, 器件电导则逐渐减小, 对应突触权重的 抑制过程. 该结果表明 $I T O / \mathrm{CsPbBr}_{3}: \mathrm{PVP} / \mathrm{Au}$ 忆阻器成 功模拟了突触可塑性 ${ }^{[26]}$.

为进一步测试器件突触可塑性模拟的可重复性, 如图 5(a) 所示，在各 50个正/反方向连续尖峰脉冲 (+/-3 V, $50 \mathrm{~ms}$ )的交替刺激下(图5(a)上图), 器件响应电 流(图5(a)下图)实现了周期性的增大和减小，每个循环 扫描中均可实现HRS与LRS的转换操作, 说明在ITO/ $\mathrm{CsPbr}_{3}: \mathrm{PVP} / \mathrm{Au}$ 忆阻器中突触权重增强和抑制的过程 有较高的可重复性; 并且在同一周期内经多次脉冲刺 激后电流变化逐渐变小, 在负脉冲刺激下电导在刺激 周期内达到饱和，正脉冲刺激下电导增加量逐渐减小. 该结果表明器件很好地模拟了生物突触中的长时程增 强作用(long-term potentiation, LTP)和长时程抑制作用 (long-term depression, LTD $)^{[27]}$. 图5(b)显示了对器件进 行HRS与LRS切换的可重复性测试结果, 施加交流矩形 脉冲(幅度为 $2 \mathrm{~V}$, 周期约 $4 \mathrm{~s}$ ) 到器件上, 长周期脉冲可保 证器件在每个半周期内实现电阻切换, 并以 $0.1 /-0.1 \mathrm{~V}$ 的电压读取电导状态. 结果表明在 250 个周期循环下, 器件依旧可以维持HRS和LRS的切换操作. 图5(c)给出 了图5(b)中的电导状态分布统计图, 可以明显区分HRS 和LRS两种状态下的电导大小, 且分布集中. 经统计, $\mathrm{HRS}$ 的电导平均值 $\mu_{\mathrm{H}}=1.12 \mathrm{mS}$, 标准差 $\sigma_{\mathrm{H}}=0.10 \mathrm{mS}$; LRS的电导平均值 $\mu_{\mathrm{L}}=3.07 \mathrm{mS}$, 标准差 $\sigma_{\mathrm{L}}=0.19 \mathrm{mS}$. 器 


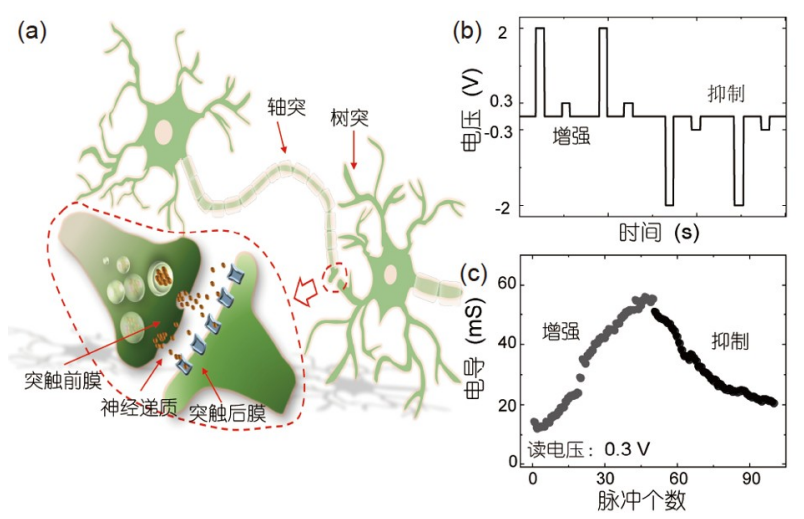

图 4 (网络版彩色) 突触可塑性模拟. (a) 神经元和突触示意图; (b) 模拟突触可塑性刺激信号的尖峰脉冲, 刺激信号幅度为 $2 \mathrm{~V}$, 读取电 导状态的电压为 $0.3 \mathrm{~V}$; (c) 脉冲刺激下电导的增强和抑制

Figure 4 (Color online) Synaptic plastic simulation. (a) Schematics of neurons and synapse; (b) spike pulses of synaptic plastic stimulation with an amplitude of $2 \mathrm{~V}$, and a voltage of $0.3 \mathrm{~V}$ for reading conductivity; (c) increase and suppression of conductivity under pulse stimulation

件的HRS中电导分布比LRS更为集中. 由此可见, ITO/ $\mathrm{CsPbBr}_{3}: \mathrm{PVP} / \mathrm{Au}$ 忆阻器在电阻切换中具有优异的可重 复性, 有利于在神经网络计算中的应用.

在生物学上, 记忆是突触的基本功能, 分为短期记 忆和长期记忆, 与STP和LTP有关 ${ }^{[28]}$. 其中, STP是突触 权重的暂时性调节, 神经元刺激信号结束后突触权重 在短期内可恢复到初始状态, 与大脑中模式识别等功 能相关 ${ }^{[29 ~ 31]}$. 其中PPF是STP的重要功能, 指的是在两 个时间间隔小的神经元刺激信号中, 第二个信号刺激 后的突触权重比前一个信号的更大, 且时间间隔越小 效果越明显 ${ }^{[32]}$. PPF指数是后一个脉冲的响应信号 $I_{\mathrm{t}}$ 与 前一个脉冲响应信号 $I_{0}$ 的比值, 即PPF指数 $=I_{\mathrm{t}} / I_{0}$. 在
$\mathrm{ITO} / \mathrm{CsPbBr}_{3}: \mathrm{PVP} / \mathrm{Au}$ 忆阻器中模拟PPF功能, 改变两个 电脉冲 $(3 \mathrm{~V}, 100 \mathrm{~ms})$ 的时间间隔 $\Delta t$, 电导变化量的 PPF 结果如图6(a)所示, $\Delta t \approx 0.17 \mathrm{~s}$ 时PPF指数为 $228 \%$; 而 $\Delta t$ $\approx 2.67 \mathrm{~s}$ 时, $\mathrm{PPF}$ 指数为 $133 \%$. 从图中可以看出, 随着 $\Delta t$ 的增大PPF指数呈指数下降, 测试结果能较好地对应指 数拟合曲线, 说明器件成功模拟了生物突触中的PPF 行为 ${ }^{[33]}$.

根据Atkinson和Shiffrin ${ }^{[34]}$ 提出的记忆多重存贮模 型(the multi-store model of memory), 短期记忆经过多 次重复刺激可转变为长期记忆, 在突触中则表现为突 触权重的非易失性. 本研究使用不同数量的正向尖峰 脉冲 $(2 \mathrm{~V}, 100 \mathrm{~ms})$ 施加到 $\mathrm{ITO} / \mathrm{CsPbBr}_{3}: \mathrm{PVP} / \mathrm{Au}$ 忆阻器 的上电极, 随后以 $0.1 \mathrm{~V}$ 的读电压读取器件电导的变化 情况. 结果如图6(b)所示, 10 个尖峰脉冲刺激后, 电导 在 $200 \mathrm{~s}$ 内降低到原来的 $20 \%$ 以下; 脉冲数量增加到 70 个以上时，经过 $180 \mathrm{~s}$, 电导仍保持在 $60 \%$ 以上; 继续增 大脉冲数量, 电导的非易失性则继续提升, 但提升效果 变弱. 上述结果表明本忆阻器可以实现短期记忆向长 期记忆的转变 ${ }^{[33]}$.

除脉冲时序因素外, 刺激的强度也会影响突触权 重的改变. 如图6(c)所示, 对ITO/CsPbBr $: \mathrm{PVP} / \mathrm{Au}$ 忆阻 器施加不同大小电压的正向尖峰脉冲, 随着电压的增 加, 器件响应电流增大; 且在 $1 \mathrm{~V}$ 脉冲下, 电流在 $10 \mathrm{~s}$ 内 便达到饱和值, 不再继续增加. 而在 $2 \mathrm{~V}$ 脉冲下, $25 \mathrm{~s}$ 后 才趋近饱和; $3 \mathrm{~V}$ 时, $35 \mathrm{~s}$ 内尚未观察到饱和现象. 我们 推测继续使用脉冲刺激, 器件的响应电流将进一步增 大. 在施加反向尖峰脉冲时, $-3 \mathrm{~V}$ 脉冲刺激下的器件电 流迅速减小; $-2 \mathrm{~V}$ 脉冲刺激下则缓慢减小且变化幅度 较小, 与图3(b)中的 $I-V$ 曲线对应. 而- $1 \mathrm{~V}$ 脉冲下的器件
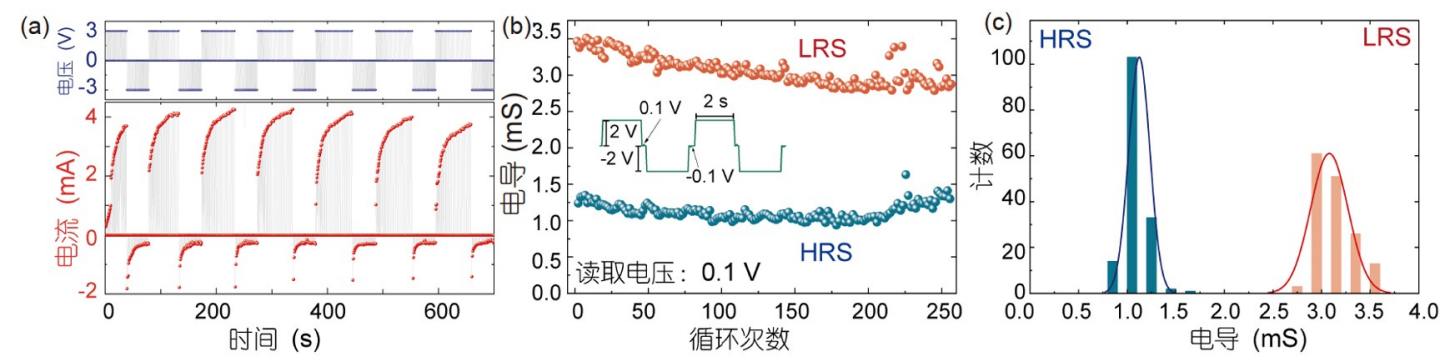

图 5 (网络版彩色) 突触权重的增强与抑制测试. (a) 正负尖峰脉冲循环刺激下的电流响应(下图). 脉冲幅值为 $3 \mathrm{~V}$, 脉宽为 $100 \mathrm{~ms}$, 每 50 个尖峰脉 冲电压方向转变 1 次 (上图). (b) 电阻变换的可重复性测试, 施加电压为周期约 $4 \mathrm{~s}$ 、幅值为 2 V 的交流矩形脉冲(插图). (c) 图(b)中的HRS和LRS的 电导分布统计

Figure 5 (Color online) Tests of synaptic weight enhancement and inhibition. (a) Current response under cyclic stimulation of positive and negative spikes (below). The pulse amplitude is $3 \mathrm{~V}$, the pulse width is $100 \mathrm{~ms}$, and the pulse voltage direction changes once every 50 spikes (up). (b) The resistance-transformation repeatability test, applied to a rectangular AC pulse with a period of about $4 \mathrm{~s}$ and an amplitude of $2 \mathrm{~V}$ (inset). (c) The conductivity distribution of HRS and LRS under the test results from (b) 

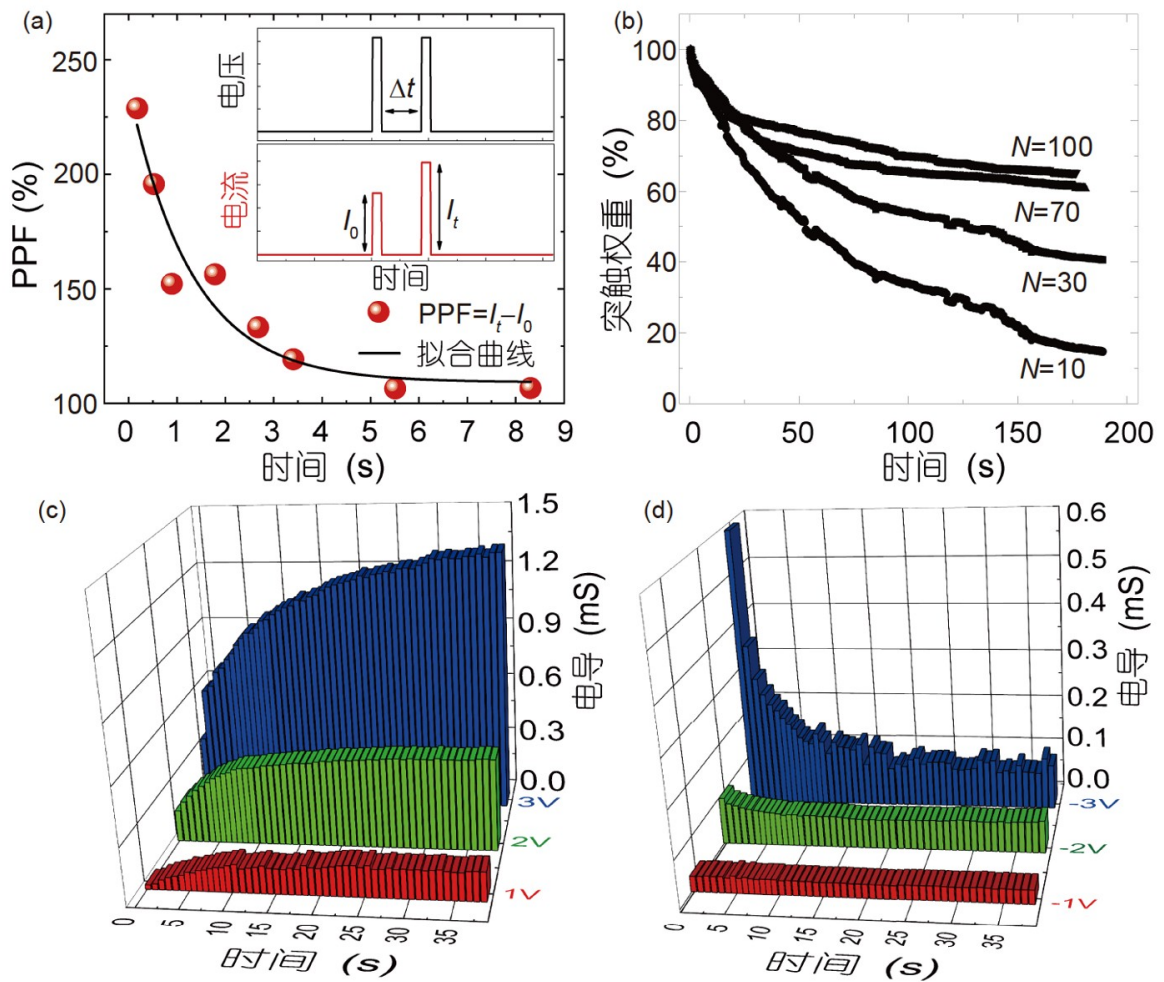

图 6 (网络版彩色)突触可塑性电学测试. (a) PPF行为模拟. 插图为脉冲示意图(3 V, $100 \mathrm{~ms}$ ). (b) STP与LTP模拟, 分别在10、30、70和100个脉 冲 $(2 \mathrm{~V}, 100 \mathrm{~ms})$ 刺激后, 使用 $0.1 \mathrm{~V}$ 的读电压读取电导变化, 图中为归一化的电导变化. 幅度为 $1 、 2 、 3 \mathrm{~V}(\mathrm{c})$ 和 $-1 、-2 、-3 \mathrm{~V}(\mathrm{~d})$ 的连续尖峰脉冲刺 激下的电导响应, 读电压为 $0.1 \mathrm{~V}$

Figure 6 (Color online) Electrical tests of synaptic plasticity. (a) PPF behavior simulation. The inset is a pulse diagram (3 V, $100 \mathrm{ms)}$ ). (b) STP and LTP simulation. After 10, 30, 70 and 100 pulses $(2 \mathrm{~V}, 100 \mathrm{~ms})$ stimulation, respectively, the conductivity changes were read with a read voltage of $0.1 \mathrm{~V}$. The conductivity curves have been normalized. Conductance response to continuous peak pulses of $1,2,3 \mathrm{~V}(\mathrm{c})$ and $-1,-2,-3 \mathrm{~V}(\mathrm{~d})$. The read voltage is $0.1 \mathrm{~V}$

电流无明显变化, 说明该幅值下的负脉冲信号对器件 电导无调节作用. 正负脉冲下的非对称电流响应与器 件上下电极材料的差异以及电极与阻变层的界面不一 致有关. 刺激脉冲电压幅值越大, $\mathrm{ITO} / \mathrm{CsPbr}_{3}: \mathrm{PVP} / \mathrm{Au}$ 忆阻器的响应电流越大，实现生物突触的脉冲幅值依 赖可塑性(spike-amplitude dependent plasticity, SADP) 模拟 ${ }^{[14]}$.

\section{3 结论}

本研究利用溶液法制备了结构为 $\mathrm{ITO} / \mathrm{CsPbBr}$ : $\mathrm{PVP} / \mathrm{Au}$ 的钙钛矿忆阻器. 通过高温退火生长 $\mathrm{CsPbBr}_{3}$ 纳
米晶体, 包裹在 $\mathrm{CsPbBr}_{3}$ 外的PVP隔绝了大气环境, 避免 易受氧化的 $\mathrm{CsPbr}_{3}$ 与空气直接接触, 从而使忆阻器能 在空气中长期存放, 并依然保持良好的忆阻特性. 在模 拟突触行为的测试中, $I T O / \mathrm{CsPbBr}_{3}: \mathrm{PVP} / \mathrm{Au}$ 忆阻器表 现出优异的操作重复性, 并实现了生物突触功能的模 拟，包括突触可塑性、LTP和STP、SATP、PPF、短期 记忆和长期记忆以及两者的转变. 得益于良好的稳定 性和突触功能的模拟, ITO/CsPbBr 3 : $\mathrm{PVP} / \mathrm{Au}$ 忆阻器有 望应用于神经形态计算领域，为打破传统计算体系的 瓶颈、提升计算速度、促进新一代计算机体系的建立 提供了新的可能性.

\section{参考文献}

1 Lecun Y, Bengio Y, Hinton G. Deep learning. Nature, 2015, 521: 436-444

2 Yao P, Wu H, Gao B, et al. Face classification using electronic synapses. Nat Commun, 2017, 8: 15199

3 Krogh A. What are artificial neural networks? Nat Biotechnol, 2008, 26: 195-197 
4 Ding K, Wang J, Zhou Y, et al. Phase-change heterostructure enables ultralow noise and drift for memory operation. Science, 2019, 366: 210-215

5 Edwards J, Keefe S O. Eager recirculating memory to alleviate the von Neumann Bottleneck. In: Proceedings of the 2016 IEEE Symposium Series on Computational Intelligence (SSCI). New Jersey: IEEE, 2016. 1-5

6 Bullmore E, Sporns O. Complex brain networks: Graph theoretical analysis of structural and functional systems. Nat Rev Neurosci, 2009, 10: 186198

7 Eryilmaz S B, Kuzum D, Jeyasingh R, et al. Brain-like associative learning using a nanoscale non-volatile phase change synaptic device array. Front Neurosci, 2014, 8: 205

8 Torrejon J, Riou M, Araujo F A, et al. Neuromorphic computing with nanoscale spintronic oscillators. Nature, 2017, 547: 428-431

9 Ho V M, Lee J A, Martin K C. The cell biology of synaptic plasticity. Science, 2011, 334: 623-628

10 Chua L. Memristor-The missing circuit element. IEEE Trans Circuit Theor, 1971, 18: 507-519

11 van de Burgt Y, Lubberman E, Fuller E J, et al. A non-volatile organic electrochemical device as a low-voltage artificial synapse for neuromorphic computing. Nat Mater, 2017, 16: 414-418

12 Wang Z Q, Xu H Y, Li X H, et al. Synaptic learning and memory functions achieved using oxygen ion migration/diffusion in an amorphous InGaZnO memristor. Adv Funct Mater, 2012, 22: 2759-2765

13 Cheng P, Sun K, Hu Y H. Memristive behavior and ideal memristor of 1T phase $\mathrm{MoS}_{2}$ nanosheets. Nano Lett, 2016, 16: 572-576

14 Chen L, Wang L, Peng Y, et al. A van der Waals synaptic transistor based on ferroelectric $\mathrm{Hf}_{0.5} \mathrm{Zr}_{0.5} \mathrm{O}_{2}$ and $2 \mathrm{D}$ tungsten disulfide. Adv Electron Mater, 2020, 6: 2000057

15 Yang W S, Noh J H, Jeon N J, et al. High-performance photovoltaic perovskite layers fabricated through intramolecular exchange. Science, 2015, 348: $1234-1237$

16 Veldhuis S A, Boix P P, Yantara N, et al. Perovskite materials for light-emitting diodes and lasers. Adv Mater, 2016, 28: 6804-6834

17 Kagan C R, Mitzi D B, Dimitrakopoulos C D. Organic-inorganic hybrid materials as semiconducting channels in thin-film field-effect transistors. Science, 1999, 286: 945-947

18 Li C, Lu X, Ding W, et al. Formability of $\mathrm{ABX}_{3}(\mathrm{X}=\mathrm{F}, \mathrm{Cl}, \mathrm{Br}, \mathrm{I})$ halide perovskites. Acta Crystlogr B Struct Sci, 2008, 64: 702-707

19 Xiao Z, Song Z, Yan Y. From lead halide perovskites to lead-free metal halide perovskites and perovskite derivatives. Adv Mater, 2019, 31: e1803792

20 Gong Y, Wang Y, Li R, et al. Tailoring synaptic plasticity in a perovskite QD-based asymmetric memristor. J Mater Chem C, 2020, 8: 2985-2992

21 John R A, Yantara N, Ng Y F, et al. Ionotronic halide perovskite drift-diffusive synapses for low-power neuromorphic computation. Adv Mater, 2018, 30: e1805454

22 Wu Y, Wei Y, Huang Y, et al. Capping $\mathrm{CsPbBr}_{3}$ with $\mathrm{ZnO}$ to improve performance and stability of perovskite memristors. Nano Res, 2017, 10: 1584-1594

23 Chua L. Resistance switching memories are memristors. In: Chua L, Adamatzky A, Sirakoulis G C, eds. Handbook of Memristor Networks. Berlin: Springer, 2019. 197-230

24 Zhu X, Du C, Jeong Y J, et al. Emulation of synaptic metaplasticity in memristors. Nanoscale, 2017, 9: 45-51

25 Bi G, Poo M. Synaptic modifications in cultured hippocampal neurons: Dependence on spike timing, synaptic strength, and postsynaptic cell type. J Neurosci, 1998, 18: 10464-10472

26 Ullman S. Using neuroscience to develop artificial intelligence. Science, 2019, 363: 692-693

27 Zhou Y, Han S T, Xu Z X, et al. The strain and thermal induced tunable charging phenomenon in low power flexible memory arrays with a gold nanoparticle monolayer. Nanoscale, 2013, 5: 1972-1979

28 Lau P Y P, Katona L, Saghy P, et al. Long-term plasticity in identified hippocampal GABAergic interneurons in the CA1 area in vivo. Brain Struct Funct, 2017, 222: 1809-1827

29 Abbott L, Regehr W G. Synaptic computation. Nature, 2004, 431: 796-803

30 Zucker R S, Regehr W G. Short-term synaptic plasticity. Annu Rev Physiol, 2002, 64: 355-405

31 Merolla P A, Arthur J V, Alvarez-Icaza R, et al. A million spiking-neuron integrated circuit with a scalable communication network and interface. Science, 2014, 345: 668-673

32 Li B, Liu Y, Wan C, et al. Mediating short-term plasticity in an artificial memristive synapse by the orientation of silica mesopores. Adv Mater, 2018, 30: 1706395

33 Ma F, Zhu Y, Xu Z, et al. Optoelectronic perovskite synapses for neuromorphic computing. Adv Funct Mater, 2020, 30: 1908901

34 Atkinson R C, Shiffrin R M. Human memory: A proposed system and its control processes. In: Spence K W, Spence J T, eds. The Psychology of Learning and Motivation. New York: Academic Press, 1968. 89-195 


\title{
Properties of memristor based on $\mathrm{CsPbBr}_{3}$ perovskite for neuromorphic computing
}

\author{
Ziquan Ni, Yueting Zheng, Hailong $\mathrm{Hu}$, Tailiang Guo \& Fushan $\mathrm{Li}^{*}$ \\ College of Physics and Information Engineering, Fuzhou University, Fuzhou 350116, China \\ * Corresponding author, E-mail: fsli@fzu.edu.cn
}

In the past few decades, the application of electronics and computers has dramatically changed the way that we learn, work, and live. Advances in semiconductor technology have enabled computers to perform increasingly well. The reduction in chip size has led to lower preparation costs, faster computer computing rates, and less power consumption. More than 50 years have passed since the development of Moore's law, and the characteristic length of silicon-based transistors is getting closer to the physical limit. On the other hand, conventional computer systems based on the von Neumann Architecture have additional latency and power consumption due to the separation of the computation and storage centers, leading to the emergence of the von Neumann Bottleneck, which limits the further improvement of the computational speed. In this background, neuromorphic computing inspired by the human brain has attracted a lot of attention in recent years. This integrated computation and storage center architecture can provide highly parallel, fast, efficient, and lowenergy computing and storage to overcome the von Neumann bottleneck.

Unlike the current mainstream neuromorphic computing that relies on software algorithms, memristors can mimic the synaptic function of biological nerves and thus build electronic devices that implement neuromorphic computing at the physical level. Nowadays, computer systems on silicon-based chip have great limitations and face new challenges for further development. The memristor-based neuromorphic computing system provides an alternative way to realize the integration of memory and computation, bio-inspired parallel computing and efficient reconfigurable memory computer system under the development needs of big data and internet of everything. To date, several materials have been applied to the development of memristors, such as oxides, two-dimensional materials, organic materials. However, these materials have certain limitations, such as complicated preparation processes, poor stability and reliability, and insufficient bionic properties. While perovskites have excellent electronic properties, which is widely used in light-emitting diodes, solar cells, and other fields. Perovskites are suitable for the preparation of memristive devices because of the advantages of high defect tolerance, high carrier mobility, and electron capture behavior. In recent years, perovskite-based artificial synapses have also been gradually developed, but they still have the problems of lack of stability and performance.

Herein, we reported a highly stable memristor prepared with cesium lead bromide $\left(\mathrm{CsPbBr}_{3}\right)$ perovskite and polyvinylpyrrolidone (PVP) by a one-step method with the structure of $\mathrm{ITO} / \mathrm{CsPbBr}_{3}: \mathrm{PVP} / \mathrm{Au}$. We used $\mathrm{CsPbBr}$ perovskite as the resistive switching layer material and added PVP to the precursor solution to prepare memristors that can be used for neuromorphic computing. After different annealing temperatures, $\mathrm{CsPbBr}_{3}$ crystals with different sizes were formed, and the device annealed at $250^{\circ} \mathrm{C}$ had the most excellent performance. The ITO/CsPbBr $: \mathrm{PVP} / \mathrm{Au}$ memristor device still maintains excellent performance when exposed to air for $9 \mathrm{~d}$, exhibiting excellent stability. Meanwhile, our device successfully simulates biological synaptic behavior, including synaptic plasticity, long-term potentiation (LTP) and short-term potentiation (STP), amplitude-dependent plasticity, paired-pulse facilitation (PPF), short-term and long-term memory. The excellent performance means that our devices can be widely used in neuromorphic computing systems, which is a step forward for the development of next-generation computer systems.

\section{$\mathrm{CsPbBr}_{3}$, perovskite, memristor, neuromorphic computation, artificial synapse}

